\title{
Detection and mechanistic investigation of halogenated benzoquinone induced DNA damage by photoelectrochemical DNA sensor
}

\author{
Suping Jia $\cdot$ Ben-Zhan Zhu $\cdot$ Liang-Hong Guo
}

Received: 17 March 2010/Revised: 22 April 2010 /Accepted: 26 April 2010 / Published online: 23 May 2010

(C) Springer-Verlag 2010

\begin{abstract}
Halogenated phenols are widely used as biocides and are considered to be possibly carcinogenic to humans. In this report, a previously developed photoelectrochemical DNA sensor was employed to investigate DNA damage induced by tetra-halogenated quinones, the in vivo metabolites of halogenated phenols. The sensor surface was composed of a double-stranded DNA film assembled on a $\mathrm{SnO}_{2}$ semiconductor electrode. A DNA intercalator, $\mathrm{Ru}$ $(\text { bpy })_{2}(\mathrm{dppz})^{2+}$, was allowed to bind to the DNA film and produce photocurrent upon light irradiation. After the DNA film was exposed to $300 \mu \mathrm{M}$ tetrafluoro-1,4-benzoquinone (TFBQ), the photocurrent dropped by $20 \%$. In a mixture of $300 \mu \mathrm{M}$ TFBQ and $2 \mathrm{mM} \mathrm{H}_{2} \mathrm{O}_{2}$, the signal dropped by $40 \%$. The signal reduction indicates less binding of $\mathrm{Ru}$ $(\mathrm{bpy})_{2}(\mathrm{dppz})^{2+}$ due to structural damage of ds-DNA in the film. Similar results were obtained with tetra-1,4-chlorobenzoquinone (TCBQ), although the signal was not reduced as much as TFBQ. Fluorescence measurement showed that TFBQ $/ \mathrm{H}_{2} \mathrm{O}_{2}$ generated more hydroxyl radicals than $\mathrm{TCBQ} / \mathrm{H}_{2} \mathrm{O}_{2}$. Gel electrophoresis proved that the two benzoquinones produced DNA strand breaks together with $\mathrm{H}_{2} \mathrm{O}_{2}$, but not by themselves. Using the photoelectrochemical sensor, it was also found that TCBQ covalently bound with DNA did not produce additional oxidative damage in the presence of $\mathrm{H}_{2} \mathrm{O}_{2}$. The combined photoelectrochemistry, gel electrophoresis, and fluorescence data revealed distinctive differences between TFBQ and TCBQ in terms of DNA adduct formation and hydroxyl radical generation.
\end{abstract}

S. Jia $\cdot$ B.-Z. Zhu $\cdot$ L.-H. Guo $(\square)$

State Key Laboratory of Environmental Chemistry and

Ecotoxicology, Research Center for Eco-environmental Sciences,

Chinese Academy of Sciences,

18 Shuangqing Road, P.O. Box 2871, Beijing 100085, China

e-mail: LHGuo@rcees.ac.cn
Keywords DNA damage · Photoelectrochemistry sensor. Benzoquinone

\section{Introduction}

Halogenated phenols are widely used in the pesticide industry and are ubiquitous in the environment due to their high stability and slow degradation [1, 2]. Among the halogenated phenols, pentachlorophenol (PCP), which is used for antimicrobial agents, detergents, and wood preservatives, has been listed by the US Environmental Protection Agency as a priority pollutant [3]. It is also classified as a Group 2B environmental carcinogen by the International Agency for Research on Cancer [4]. The metabolism and toxicology of PCP has been investigated extensively [5-7]. The carcinogenesis of PCP is believed to involve the in vivo enzyme-mediated biotransformation of PCP to its reactive metabolites such as tetrachlorohydroquinone (TCHQ) and tetrachloro-1,4-benzoquinone (TCBQ). Several modes of action have been investigated for DNA damage induced by these metabolites. DNA adducts were identified in calf thymus DNA reacted with TCBQ [8], in human HeLA S3 tumor cells treated with TCHQ [9], and in rats exposed to PCP [10]. Structure of a deoxyguanosine $(\mathrm{dG}) / \mathrm{TCBQ}$ adduct was characterized carefully, and was found to be a dichlorobenzoquinone nucleoside [11]. The reaction was dependent on the type of nucleobases, as TCBQ reacted more readily with $\mathrm{dG}$ than with other bases. In another DNA adduct formation mechanism, PCP was found to be oxidized by horseradish peroxidase $/ \mathrm{H}_{2} \mathrm{O}_{2}$ to the corresponding phenoxyl radicals, which then reacted with nucleobases to produce oxygenbound $\mathrm{C} 8 \mathrm{-dG}$ nucleoside adduct [12]. In addition to covalent adducts, oxidative DNA damage was also ob- 
served in calf thymus DNA, tumor cells and rats [8-10]. Reactive oxygen species were believed to be formed during the enzyme-catalyzed biotransformation of PCP. In the presence of $\mathrm{Cu}(\mathrm{II})$ and $\mathrm{NADPH}$, low concentrations of TCBQ induced increased production of 8-hydroxydeoxyguanosine (8-HO-dG) and abasic sites [8].

More recently, by using salicylate hydroxylation assay and electron spin resonance method, it was found that halogenated quinones produced hydroxyl radicals (HO-) in the presence of $\mathrm{H}_{2} \mathrm{O}_{2}$ in a mechanism independent of transition metal ions [13-15]. It was inferred that a nucleophilic reaction might take place between TCBQ and $\mathrm{H}_{2} \mathrm{O}_{2}$, forming a trichlorohydroperoxyl-1,4-benzoquinone (TrCBQ-OHO-) intermediate, which would decompose homolytically to produce HO. Metal-independent production of HO from $\mathrm{H}_{2} \mathrm{O}_{2}$ was also observed with several other halogenated quinones including 2,5-dichloro-1,4-benzoquione (2,5DCBQ), 2-chloro-1,4-benzoquione (2-CBQ), tetrafluoro1,4-benzoquinone (TFBQ) and tetrabromo-1,4-benzoquinone (TBBQ).

Similar to PCP, the toxicity of other chlorinated phenols such as 2,4,6-trichlorophenol (2,4,6-TCP), 2,4,5-trichlorophenol (2,4,5-TCP), and 2,4-dichlorophenol (2,4-DCP) have also been well-documented. Reactivity of these chlorophenols toward $\mathrm{dG}$ and calf thymus DNA following activation by horseradish peroxidase $/ \mathrm{H}_{2} \mathrm{O}_{2}$ has been established [16-18], and the formation of 2,5-DCBQDNA and 2,6-DCBQ-DNA adducts was observed [19].

In the studies described above, several well-established techniques were employed in the identification and characterization of damaged DNA. 8-HO-dG is a commonly used marker for oxidative DNA damage, and is identified using HPLC separation followed by online electrochemical detection. DNA strand breaks are observed by gel electrophoresis. For DNA adduct identification and quantification, ${ }^{32} \mathrm{P}$ post-labeling is the method of choice, although the procedure is very time-consuming, including enzymatic digestion of DNA sample, purification, labeling with ${ }^{32} \mathrm{P}$, and TLC or PAGE analysis [20]. Recently, we developed a photoelectrochemical DNA sensor for the rapid detection of structural DNA damage [21-23]. The sensor surface was composed of a double-stranded DNA (ds-DNA) film assembled on a $\mathrm{SnO}_{2}$ semiconductor electrode. A DNA intercalator, $\mathrm{Ru}(\mathrm{bpy})_{2}(\mathrm{dppz})^{2+}$, was allowed to bind to the DNA film and produce photocurrent upon light irradiation. After the DNA film was exposed to a DNA-damaging chemical, photocurrent would drop due to less binding of $\mathrm{Ru}(\mathrm{bpy})_{2}(\mathrm{dppz})^{2+}$ to the damaged DNA film. It was shown that the sensor was able to detect both oxidative DNA damage induced by $\mathrm{Fe}^{2+} / \mathrm{H}_{2} \mathrm{O}_{2}$, as well as DNA adducts with styrene oxide [21]. In the present work, the photoelectrochemical DNA sensor has been employed to detect DNA damage induced by tetra-halogenated benzoquinones.
We demonstrate that the sensor can detect very rapidly the DNA damage caused by the direct DNA adducts with the halogenated quinone alone, as well as by oxidative damage from their mixture with $\mathrm{H}_{2} \mathrm{O}_{2}$. With its unique feature, some information about the damage reaction mechanism can also be obtained.

\section{Experimental}

\section{Reagents}

Tin-doped indium oxide (ITO) conductive glass was supplied by Weiguang Corp (Shenzhen, People's Republic of China). Fifteen percent tin (IV) oxide, as a colloidal dispersion of 15-nm particles, was obtained from Alfa Aesar (Ward Hill, MA), so was hydrogen peroxide. Poly-(diallydimethyl ammonium chloride) (PDDA), coumarin-3-carboxylic acid (CCA), ethidium bromide, TCBQ and TFBQ were obtained from Sigma-Aldrich (St. Louis, MO). Double-stranded calf thymus DNA (ds-DNA, approximately13K base pairs) was purchased from Merck (San Diego, CA). Ru(bpy) $)_{2}(\mathrm{dppz})$ $\left(\mathrm{BF}_{4}\right)_{2}$ was synthesized according to the published procedure $[24,25]$. All other chemicals and solvents were of analytical grade. Solutions were prepared in high-purity water from a Millipore Milli-Q (Biocel) water purification system.

\section{Photoelectrochemical measurement}

In the experiment, the preparation of $\mathrm{SnO}_{2}$ nanoparticle electrodes and the fabrication of the DNA films on the $\mathrm{SnO}_{2}$ electrode was the same as previously described [21]. The concentration of PDDA and ds-DNA solution for film deposition was $2 \mathrm{mg} / \mathrm{mL}$ and $0.5 \mathrm{mg} / \mathrm{mL}$, respectively. The DNA-modified electrode was denoted as $\mathrm{SnO}_{2} / \mathrm{PDDA} / \mathrm{DNA}$. TCBQ was dissolved in $N, N$-dimethylformamide (DMF) at a concentration of $150 \mathrm{mM}$ and then diluted to $20 \mathrm{mM}$ phosphate buffer ( $\mathrm{pH}$ 7.3). TFBQ was dissolved in acetonitrile at a concentration of $150 \mathrm{mM}$ and then diluted to $20 \mathrm{mM}$ PB ( $\mathrm{pH}$ 7.3). The DNA film on the electrode was damaged by exposing to halogenated quinone alone or a mixture of halogenated quinone and $\mathrm{H}_{2} \mathrm{O}_{2}$ in $\mathrm{PB}$ buffer at $37{ }^{\circ} \mathrm{C}$ with vortex $(200 \mathrm{rpm})$ for $30 \mathrm{~min}$. A DNA film electrode with either intact or damaged DNA was first rinsed with water for $3 \mathrm{~min}$ and then reacted with $50 \mu \mathrm{M} \mathrm{Ru}(\mathrm{bpy})_{2}(\mathrm{dppz})^{2+}$ for $30 \mathrm{~min}$ in order for the signal reporter to bind to the DNA film. After the reaction, the unbound metal complex was washed off by water. Photocurrent was measured on a $\mathrm{CHI}$ $630 \mathrm{~A}$ electrochemical analyzer $(\mathrm{CH}$ Instruments, Austin, TX) by placing the electrode in $30 \mathrm{mM}$ oxalate buffer $(\mathrm{pH}$ 5.8), using a $\mathrm{Pt}$ counter electrode, a $\mathrm{Ag} / \mathrm{AgCl}(3 \mathrm{M} \mathrm{KCl})$ reference electrode, and a bias voltage of $+0.1 \mathrm{~V}$. 


\section{Gel electrophoresis}

The damaged ds-DNA sample for gel electrophoresis was prepared by the incubation of $0.01 \mathrm{mg} / \mathrm{mL}$ ds-DNA with different damage reagent for $30 \mathrm{~min}$ at $37{ }^{\circ} \mathrm{C}$. The incubated DNA sample was then electrophoresed on a $0.6 \%$ agarose gel in $0.5 \times$ TBE buffer $(45 \mathrm{mM}$ Tris, $45 \mathrm{mM}$ boric acid, $1 \mathrm{mM}$ EDTA, $\mathrm{pH} 8.0)$ and $0.5 \mu \mathrm{g} / \mathrm{mL}$ ethidium bromide for $35 \mathrm{~min}$ at $80 \mathrm{~V}$.

\section{Fluorescence measurement}

Fluorescence intensity was measured on a Thermo Electron Varioskan Flash luminescence spectrometer (Waltham, MA), using $395 \mathrm{~nm}$ excitation, $450 \mathrm{~nm}$ emission, a 5-nm slit width, and a 430-nm emission cut-off filter. A well containing $1 \mathrm{mM}$ CCA, $300 \mu \mathrm{M}$ halogenated quinone, and $2 \mathrm{mM} \mathrm{H} \mathrm{H}_{2} \mathrm{O}_{2}$ in $20 \mathrm{mM}$ phosphate buffer ( $\mathrm{pH} \mathrm{7.3)} \mathrm{was}$ shaken for $30 \mathrm{~min}$ at $37{ }^{\circ} \mathrm{C}$ before the measurement. The fluorescence intensity from wells containing a mixture of $\mathrm{CCA}$ and halogenated quinone (no $\mathrm{H}_{2} \mathrm{O}_{2}$ ) was used as the control, and the wells containing CCA only were used as the blank.

\section{Results and discussion}

As described in the "Introduction" section, halogenated quinones are electrophilic agents that have been proven experimentally to bind covalently to the nucleophilic sites in calf thymus DNA and poly-nucleosides to form DNA adducts, preferentially with dG [8-12]. In addition, halogenated quinones also produced highly reactive hydroxyl radical (HO-) in the presence of $\mathrm{H}_{2} \mathrm{O}_{2}$ [13-15]. A number of studies have shown that $\mathrm{HO}$ can induce several classes of DNA oxidative damage, including single-strand break, double-strand break, abasic sites, and base oxidation [26]. It has been shown that the photoelectrochemical DNA sensor we developed previously can detect DNA damage caused either by DNA adducts with styrene oxide, or by $\mathrm{HO}$. generated in $\mathrm{Fe}^{2+}$-mediated Fenton Reaction [21]. Therefore, the sensor can, in principle, detect DNA damage induced by halogenated quinones in the absence and presence of $\mathrm{H}_{2} \mathrm{O}_{2}$.

DNA damage by TFBQ was first investigated by the photoelectrochemical sensor. In the experiment, a DNA film was fabricated on a $\mathrm{SnO}_{2}$ nanoparticle electrode using the layer-by-layer electrostatic self-assembly approach. After binding of the signal reporter $\mathrm{Ru}(\mathrm{bpy})_{2}(\mathrm{dppz})^{2+}$ to the DNA film, photoelectrochemical signal was measured in an oxalate solution. As shown in Fig. 1a, upon light illumination, a relatively stable photocurrent with a magnitude of approximately $730 \mathrm{nA}$ was recorded. However, if the sensor was first incubated in $300 \mu \mathrm{M}$ TFBQ before binding with $\mathrm{Ru}(\mathrm{bpy})_{2}(\mathrm{dppz})^{2+}$, the photocurrent decreased to $586 \mathrm{nA}$. The reduction in photocurrent could be attributed to TFBQ/DNA adduct formation. $\mathrm{Ru}$ $(\text { bpy })_{2}(\mathrm{dppz})^{2+}$ is a DNA intercalator and binds selectively to the stacked base pairs in double-stranded DNA. DNA adducts with bulky molecules such as TFBQ introduce spatial hindrance to DNA base paring and change its double-helical structure, thus resulting in less bound signal reporters. In our previous work, we have shown by fluorescence that styrene oxide/DNA adducts reduced the binding of $\mathrm{Ru}(\mathrm{bpy})_{2}(\mathrm{dppz})^{2+}$ with double-stranded calf thymus DNA [21]. Another possible reason for the reduction of photocurrent is that $\mathrm{Ru}(\mathrm{bpy})_{2}(\mathrm{dppz})^{2+}$ binding is not affected, but the electron transfer rate from $\mathrm{Ru}$ $(\text { bpy })_{2}(\mathrm{dppz})^{2+}$ to the electrode is slowed down by the adducts. This is unlikely in our system, because the DNA molecules are deposited on the electrode by electrostatic adsorption, and they should orientate mostly along the horizontal direction. Therefore, interfacial electron transfer does not go along the DNA chain, but rather through the underlying PDDA layer. Also shown in Fig. $1 \mathrm{a}$ is the
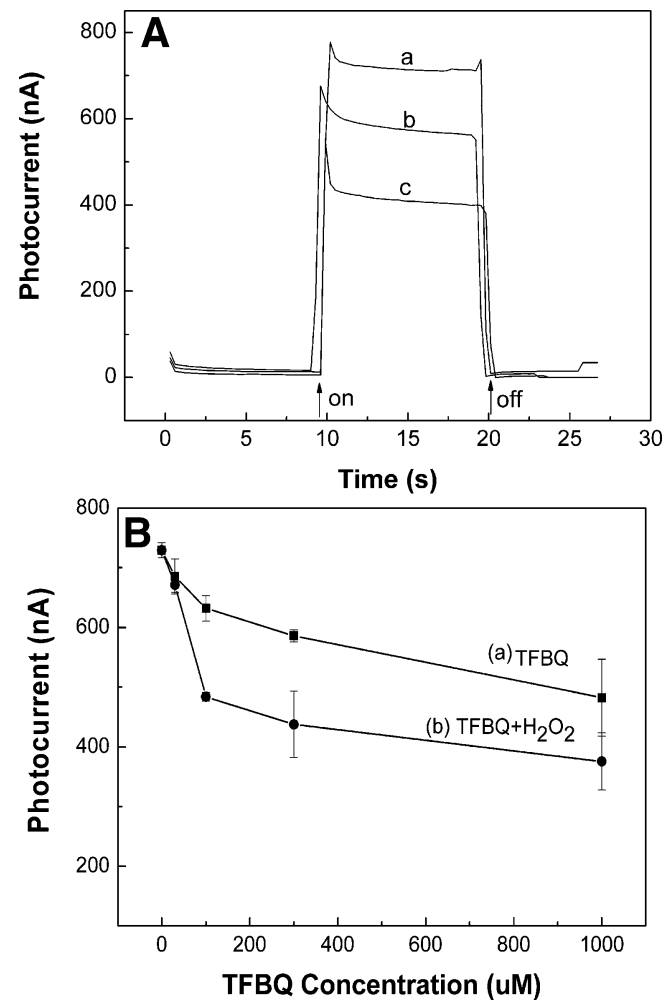

Fig. 1 a Photocurrent of $\mathrm{Ru}(\mathrm{bpy})_{2}(\mathrm{dppz})^{2+}$ bound to DNA electrode after it was exposed to (a) $20 \mathrm{mM}$ PB buffer (pH 7.3) for $30 \mathrm{~min},(b)$ $300 \mu \mathrm{M}$ TFBQ for $30 \mathrm{~min}$, (c) $300 \mu \mathrm{M}$ TFBQ and $2 \mathrm{mM} \mathrm{H}_{2} \mathrm{O}_{2}$ for 30 min. Excitation light was switched on and off as indicated. b Photocurrent response of $\mathrm{Ru}(\mathrm{bpy})_{2}(\mathrm{dppz})^{2+}$ intercalated into the $\mathrm{SnO}_{2} /$ PDDA/DNA film as a function of the concentration of TFBQ in $(a)$ TFBQ alone, (b) TFBQ and $\mathrm{H}_{2} \mathrm{O}_{2}$ 
photoelectrochemical response of the sensor after it was exposed to a mixed solution of $300 \mu \mathrm{M}$ TFBQ and $2 \mathrm{mM}$ $\mathrm{H}_{2} \mathrm{O}_{2}$. The current dropped by $40 \%$ to $450 \mathrm{nA}$. The reason for the larger loss of signal is that, in addition to forming DNA adducts, TFBQ may also react with $\mathrm{H}_{2} \mathrm{O}_{2}$ and generate HO that oxidizes DNA bases. Similar to DNA adducts, the oxidative damage also reduces the intercalation sites in DNA for the signal reporter.

Although photoelectrochemical sensors cannot identify the type of DNA damage (adduct or oxidative), they offer some unique advantages over the conventional techniques. One advantage is high sensitivity. As can be seen in Fig. 1b, DNA damage by $30-100 \mu \mathrm{M}$ TFBQ was detected, whereas in ${ }^{32} \mathrm{P}$ post-labeling method the concentration was in the millimolar range [8]. Secondly, DNA usage in the sensor method is very low. It has been determined that the amount of DNA immobilized in a film is $3.2 \mathrm{ng} \mathrm{mm}^{-2}$ [27]. This is much less than the amount (micrograms) needed for ${ }^{32} \mathrm{P}$ post-labeling and gel electrophoresis experiments. Thirdly, once the DNA film is prepared on the sensor surface, DNA damage detection is simple and rapid. On the contrary, ${ }^{32} \mathrm{P}$ post-labeling method involves multiple steps and is very time-consuming.

In addition to TFBQ, TCBQ was also investigated. Figure 2 depicts the photocurrent signal of the DNA sensor exposed to TCBQ alone, and its mixture with $\mathrm{H}_{2} \mathrm{O}_{2}$, respectively. The results show that, in the absence of $\mathrm{H}_{2} \mathrm{O}_{2}$, TCBQ reduced the photocurrent, indicating covalent binding with DNA. The photocurrent follows the order TCBQ $<$ TFBQ $<$ blank, suggesting that TCBQ formed more DNA adducts than TFBQ. In the presence of $\mathrm{H}_{2} \mathrm{O}_{2}$, the photocurrent of TCBQ is higher than TFBQ. It is also higher than TCBQ alone. Because it is possible for the quinones in the mixture to carry out DNA adduct reaction and oxidative damage at the same time, interpretation of the results is not straightforward, and will be discussed later after fluorescence and gel electrophoresis experiments.

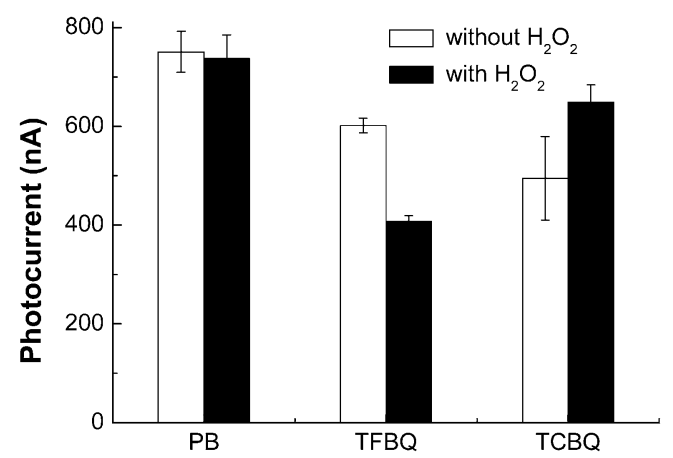

Fig. 2 Photocurrent response of $\mathrm{Ru}(\mathrm{bpy})_{2}(\mathrm{dppz})^{2+}$ bound to $\mathrm{SnO}_{2} /$ PDDA/ds-DNA electrode after the DNA film was exposed to PB buffer, $300 \mu \mathrm{M}$ TFBQ, $300 \mu \mathrm{M}$ TCBQ without $\mathrm{H}_{2} \mathrm{O}_{2}$ (empty column) or with $2 \mathrm{mM} \mathrm{H}_{2} \mathrm{O}_{2}$ (filled column)
As mentioned above, TCBQ has been shown by ESR to produce $\mathrm{HO} \cdot$ in its reaction with $\mathrm{H}_{2} \mathrm{O}_{2}$ by a metalindependent mechanism [15]. As we know, the most widely accepted mechanism for $\mathrm{HO}$ production is through the metal ion mediated decomposition of hydrogen peroxide, the Fenton reaction [28]. It has been shown that hydroxyl radicals can bring about extensive damage to many biological macromolecules, including protein fragmentation, lipid peroxidation, carbohydrate degradation, and oxidative DNA damage. The newly proposed mechanism for $\mathrm{HO}$ generation from reactions between halogenated quinones and $\mathrm{H}_{2} \mathrm{O}_{2}$ does not require the involvement of transition metal ions. It may partly contribute to the carcinogenesis of halogenated phenols such as hexachlorobenzene, chlorophenols, and Agent Orange, which can be metabolized in vivo to tetra-, di-, or monochlorinated quinones. To confirm the formation of HO and compare the reactivity of the two halogenated quinones, fluorescence measurement was carried out. Coumarin-3-carboxylic acid (CCA) is a non-fluorescent molecule in aqueous solutions. It can react directly with $\mathrm{HO}$ to produce the highly fluorescent compound 7-hydroxycoumarin-3-carboxylic acid. This reaction has been shown to be specific for the detection of HO- produced either by radiation or chemical reaction, and also quantitative, sensitive, and accurate [29, 30]. As Fig. 3 shows, when CCA was added into $300 \mu \mathrm{M}$ halogenated quinone alone (c, e), the fluorescence intensity did not show any change compared with the blank $(a, b)$. But the fluorescence intensity increased substantially after CCA was reacted with a mixture of $300 \mu \mathrm{M}$ halogenated quinone and $2 \mathrm{mM} \mathrm{H}_{2} \mathrm{O}_{2}(\mathrm{~d}, \mathrm{f})$. The intensity in TFBQ/ $\mathrm{H}_{2} \mathrm{O}_{2}$ is about twice as much as that of TCBQ, indicating that TFBQ/ $\mathrm{H}_{2} \mathrm{O}_{2}$ produced more $\mathrm{HO}$ - than TCBQ/ $\mathrm{H}_{2} \mathrm{O}_{2}$.

To further investigate the effect of quinone generated HO on DNA, gel electrophoresis of DNA samples after reaction with quinone $/ \mathrm{H}_{2} \mathrm{O}_{2}$ was conducted. Because calf thymus DNA is a heterogeneous polymer of various chain

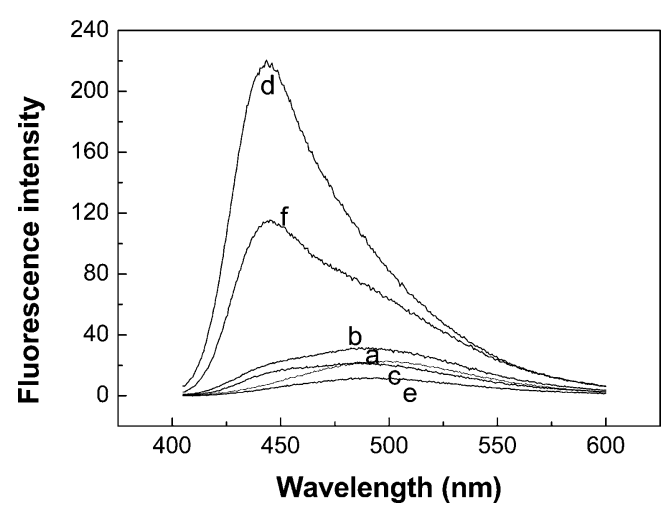

Fig. 3 Fluorescence of $1 \mathrm{mM} \mathrm{CCA}$ after reacting with (a) $20 \mathrm{mM}$ PB buffer, (b) $20 \mathrm{mM} \mathrm{PB}$ and $2 \mathrm{mM} \mathrm{H}_{2} \mathrm{O}_{2}$, (c) $300 \mu \mathrm{M}$ TFBQ, (d) $300 \mu \mathrm{M}$ TFBQ and $2 \mathrm{mM} \mathrm{H}_{2} \mathrm{O}_{2}$, (e) $300 \mu \mathrm{M}$ TCBQ, (f) $300 \mu \mathrm{M}$ TCBQ and $2 \mathrm{mM} \mathrm{H}_{2} \mathrm{O}_{2}$ 
length, the intact DNA sample displayed a major band on the bottom of the image (length greater than 2,000 base pairs) and many less intense bands with shorter length (Fig. 4). Reaction with TFBQ alone did not change the pattern of DNA electrophoresis image, which suggests there is no DNA break in the reaction product. However, for the DNA samples reacted with $1 \mathrm{mM}$ TFBQ / $2 \mathrm{mM}$ $\mathrm{H}_{2} \mathrm{O}_{2}$, the major band disappeared in the image. Instead, many new bands with shorter length emerged, representing DNA breaks. For TCBQ, much higher concentration ( $2 \mathrm{mM} \mathrm{TCBQ} / 50 \mathrm{mM} \mathrm{H}_{2} \mathrm{O}_{2}$ ) was needed for the major band to lower its intensity as shown in Fig. 4b. The observation in gel electrophoresis experiments is consistent with fluorescence measurement in that TFBQ generated more $\mathrm{HO}$ - in fluorescence measurement than TCBQ, and also produced more DNA breaks in electrophoresis image. The trend is also consistent with the photoelectrochemical measurement results depicted in Fig. 2, where lower current reflects more DNA damage.

One unique feature of the photoelectrochemical DNA sensor is that the reaction is surface-based, and as such allows for easy separation between surface-bound and solution species. In our previous work, this surface reaction mode was exploited to investigate the role of DNA-associated $\mathrm{Fe}^{2+}$ ions in oxidative DNA damage [22]. It was demonstrated explicitly that $\mathrm{Fe}^{2+}$ ions indeed associated with the DNA molecules in the sensor film, and still engaged in Fenton reaction and DNA damage. The reactivity of covalently bound benzoquinones was also investigated in the current work by the sensor method. In the experiment, the DNA film electrode was assembled as usual, and then exposed to $300 \mu \mathrm{M}$ TCBQ. After rinsing with water, the sensor was then reacted with $2 \mathrm{mM} \mathrm{H}_{2} \mathrm{O}_{2}$. Finally, the electrode was allowed to bind with $\mathrm{Ru}(\mathrm{bpy})_{2}(\mathrm{dppz})^{2+}$, and the photocurrent was measured. As shown in Fig. 5, the photocurrent was

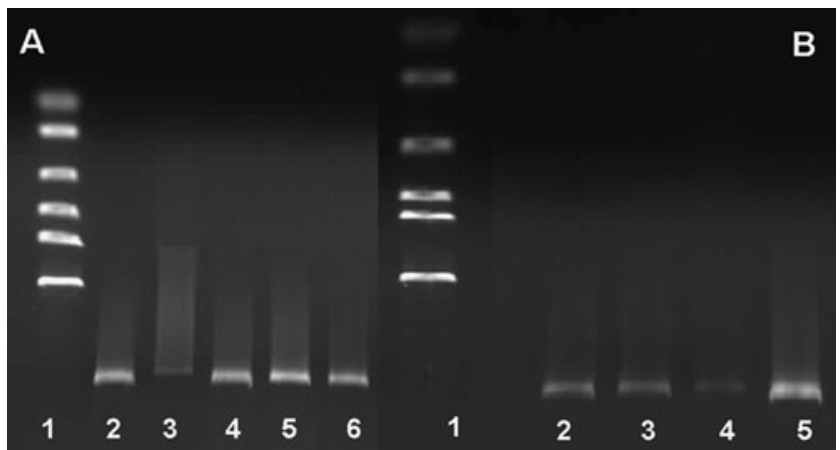

Fig. 4 Agarose gel electrophoresis of different types of DNA, a: (1) DNA marker, (2) $0.01 \mathrm{mg} / \mathrm{ml}$ CT-DNA reacted with $1 \mathrm{mM}$ TFBQ, (3) DNA reacted with $1 \mathrm{mM}$ TFBQ/2 $\mathrm{mM} \mathrm{H}_{2} \mathrm{O}_{2}$, (4) DNA reacted with $1 \mathrm{mM}$ TCBQ, (5) DNA reacted with $1 \mathrm{mM}$ TCBQ/2 mM H $\mathrm{H}_{2} \mathrm{O}_{2}$, (6) intact DNA. b (1) DNA marker, (2) $0.01 \mathrm{mg} / \mathrm{ml} \mathrm{CT-DNA} \mathrm{reacted} \mathrm{with}$ $2 \mathrm{mM}$ TCBQ, (3) DNA reacted with $2 \mathrm{mM} \mathrm{TCBQ} / 5 \mathrm{mM} \mathrm{H}_{2} \mathrm{O}_{2}$, (4) DNA reacted with $2 \mathrm{mM} \mathrm{TCBQ} / 50 \mathrm{mM} \mathrm{H}_{2} \mathrm{O}_{2}$, (5) intact DNA

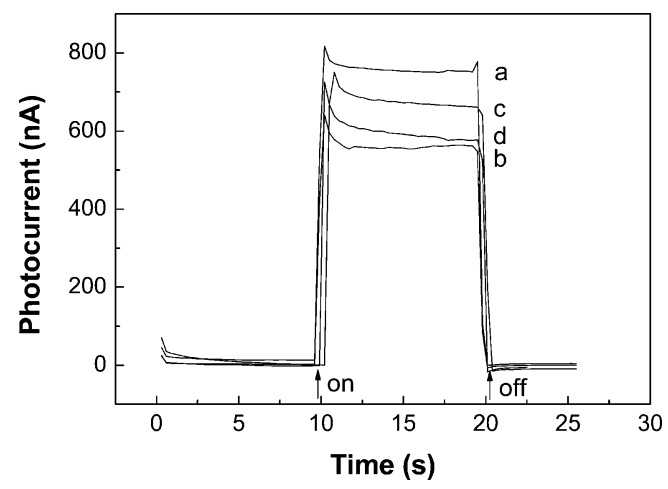

Fig. 5 Photocurrent of $\mathrm{Ru}(\mathrm{bpy})_{2}(\mathrm{dppz})^{2+}$ bound to DNA electrode after the DNA film was exposed to (a) $20 \mathrm{mM}$ PB for $1 \mathrm{~h}$, (b) $300 \mu \mathrm{M}$ TCBQ for $1 \mathrm{~h},\left(\right.$ c) $300 \mu \mathrm{M}$ TCBQ $/ 2 \mathrm{mM} \mathrm{H}_{2} \mathrm{O}_{2}$ for $1 \mathrm{~h},($ d) $300 \mu \mathrm{M}$ TCBQ for $30 \mathrm{~min}$, water rinse, then $2 \mathrm{mM} \mathrm{H}_{2} \mathrm{O}_{2}$ for $30 \mathrm{~min}$

basically the same as the electrode that was reacted with TCBQ only (no $\mathrm{H}_{2} \mathrm{O}_{2}$ ). The result suggests that TCBQ covalently bound with DNA does not produce additional oxidative damage even in the presence of $\mathrm{H}_{2} \mathrm{O}_{2}$.

\section{Conclusions}

In conclusion, DNA damage by halogenated phenol metabolites, TFBQ and TCBQ, was investigated by photoelectrochemical DNA sensor in combination with fluorescence measurement and gel electrophoresis. It was found that the two benzoquinones exhibited distinctively different reactivity in DNA damage. In the absence of $\mathrm{H}_{2} \mathrm{O}_{2}$, TCBQ induced more DNA damage than TFBQ, presumably by forming covalent adducts. However, in the mixed solution with $\mathrm{H}_{2} \mathrm{O}_{2}$, more severe DNA damage was observed with TFBQ. The HO- measured by a fluorescent probe and DNA breaks observed in gel electrophoresis are consistent with the photoelectrochemical results. The photoelectrochemical DNA sensor possesses advantages in sensitivity, sample consumption, and convenience, and offers a rapid and semi-quantitative tool for the detection of both oxidative DNA damage and covalent adduct formation, as well as for the study of reaction mechanisms.

Acknowledgment This work was supported by the National Natural Science Foundation of China (grant number 20825519, 20921063, 20890112) and the National Hi-Tech Research and Development Program of China (2006AA06Z422)

\section{References}

1. Ahlborg UG, Thunberg T (1980) Crit Rev Toxicol 7:1-35

2. Ramamoorthy S, Ramamoorthy S (1997) Chlorinated organic compounds in the environment. CRC, Boca Raton 
3. Environmental Protection Agency Working Group (1980) Ambient water quality criteria for chlorinated phenols. Environmental Protection Agency, Washington DC

4. International Agency for Research on Cancer (1991) France, Lyon

5. Seiler JP (1991) Mutat Res 257:27-47

6. Sackmauerova-Veningerova M, Uhnak J, Szokolay A, Kocan A (1981) J Chromatogr 205:194-198

7. Tsai CH, Lin PH, Waidyanatha S, Rappaport SM (2001) Chem Biol Interact 134:55-71

8. Lin P-H, Nakamura J, Yamaguchi S, Upton PB, La DK, Swenberg JA (2001) Carcinogenesis 22:627-634

9. Lin P-H, Nakamura J, Yamaguchi S, La DK, Upton PB, Swenberg JA (2001) Carcinogenesis 22:635-639

10. Lin P-H, La DK, Upton PB, Swenberg JA (2002) Carcinogenesis 23:365-369

11. Nguyen TN, Bertagnolli AB, Villalta PW, Buhlmann P, Sturla SJ (2005) Chem Res Toxicol 18:1770-1776

12. Dai J, Sloat AL, Wright MW, Manderville RA (2005) Chem Res Toxicol 18:771-779

13. Zhu B-Z, Kitrossky N, Chevion M (2000) Biochem Biophys Res Commun 270:942-946

14. Zhu B-Z, Zhao HT, Kalyanaraman B, Frei B (2002) Free Radic Biol Med 32:465-473

15. Zhu B-Z, Kalyanaraman B, Jiang G-B (2007) Proc Natl Acad Sci USA 104:17575-17578

16. Carrizo D, Grimalt JO, Fito NR, Torrent M, Sunyer J (2008) Ecotoxicol Environ Saf 71:260-266
17. Choi SH, Gu MB (2003) Anal Chim Acta 481:229-238

18. Chen J, Jiang J, Zhang F, Yu H, Zhang J (2004) Cell Boil Toxicol 20:183-196

19. Vaidyanathan VG, Villalta PW, Sturla SJ (2007) Chem Res Toxicol 20:913-919

20. Pfeifer GP (1996) Technologies for detection of DNA damage and mutations. Plenum, New York

21. Liang MM, Guo L-H (2007) Environ Sci Technol 41:658-664

22. Jia SP, Liang MM, Guo L-H (2008) J Phys Chem B 112:44614464

23. Liang MM, Jia SP, Zhu S-C, Guo L-H (2008) Environ Sci Technol 42:635-639

24. Musumeci S, Rizzarelli FS, Sammartano S, Bonomo RP (1973) Inorg Chim Acta 7:660-662

25. Edmond A, Abdulrazzak H (1990) J Chem Soc Dalton Trans $1841-1845$

26. Valko M, Morris H, Cronin MTD (2005) Curr Med Chem 12:1161-1208

27. Wei MY, Guo L-H, Chen H (2006) Microchim Acta 155:409414

28. Halliwell B, Gutteridge JMC (2007) Free radicals in biology and medicine. Oxford Univ, New York

29. Manevich Y, Held KD, Biaglow JE (1997) Radia Res 148:580 591

30. Makrigiorgos GM, Baranowska-Kortylewicz J, Bump E, Sahu SK, Berman RM, Kassis AI (1995) Free Radic Biol Med 18:669678 